\title{
YADNYA SEBAGAI PENGUATAN NILAI PENDIDIKAN KARAKTER
}

I Komang Mertayasa

Institut Agama Hindu Negeri Tampung Penyang Palangka Raya kmertayasa19@gmail.com

\begin{abstract}
Abstrak
Kebiasaan yang dilakukan oleh masyarakat terkadang tanpa disadari merupakan bagian dari pendidikan. Rangkaian pelaksanaan Panca Yadnya memiliki nilai yang dapat berfungsi sebagai Penguat Pendidikan Karakter. Namun masyarakat selama ini tidak banyak yang memahami hal tersebut, masyarakat lebih fokus pada terlaksananya Yadnya sebagai bentuk kewajiban yang timbul akibat dari kelahiran di dunia dan sebagai bentuk pelaksanaan Tri Rna, padahal dalam proses mulai dari penyiapan hingga pelaksanaan mampu untuk mendidik orangorang yang terlibat di dalamnya. Hal ini menjadikan penting karena dapat dijadikan sebagai wadah dalam penguatan pendidikan karakter. Pendidikan karakter yang dikuatkan dari rangkaian pelaksanaan Yadnya 1). Religiusitas, 2). Komunikatif, 3). Kerjasama (Gotong royong), 4). Bertanggung Jawab, dan 5). Kepedulian Sosial. Berbagai bentuk karakter yang dikuatkan dengan pelaksanaan Yadnya, baik bagi pelaku maupun orang-orang yang membantu pelaksanaanya. Kelompok suka duka merupakan organiassi tradisional hindu yang menjadi wadah dalam penguatan pendidikan karakter. Hal tersebut perlu diajarkan kepada generasi muda sehingga memiliki pemahaman yang komprehensif, dan Yadnya tidak hanya di maknai sebagai upacara ritual belaka, namun juga bagian dari pendidikan.
\end{abstract}

Kata Kunci : Yadnya, Tri Rna, Pendidikan Karakter 


\section{Pendahuluan}

Pendidikan dapat diperoleh oleh dari berbagai satuan pendidikan. Peserta didik tidak hanya memperoleh pendidikan dari lingkungan sekolah, akan tetapi juga dapat diperoleh pada lingkungan keluarga dan masyarakat serta lembaga kursus. Lingkungan keluarga dan masyarakat memberikan pendidikan melalui budaya-budaya yang merupakan kebiasaan-kebiasan yang tumbuh dan berkembang dalam lingkungan dimana individu tersebut hidup.

Undang-undang nomor 20 tahun 2013 tentang sistem pendidikan nasional menjelaskan bahwa satuan pendidikan adalah merupakan kelompok layanan pendidikan yang menyelenggarakan pendidikan pada jalur formal, nonformal, dan informal pada setiap jenjang dan jenis pendidikan, (Tim, 2003).

Saat ini pemerintah berupaya dalam membentuk dan menguatkan karakter melalui berbagai jenjang pendidikan baik formal, informal maupun non formal. Penguatan Pendidikan Karakter (PPK) selain diperoleh dalam satuan pendidikan formal, juga dapat diperoleh melalui pendidikan nonformal dan informal. PPK pada satuan pendidikan formal diselenggarakan dengan mengoptimalkan fungsi kemitraan tripusat pendidikan yang meliputi sekolah, keluarga dan masyarakat, (Tim, 2018).

Ungkapan tersebut menyiratkan bahwa lembaga pendidikan formal dalam penguatan pendidikan karakter membutuhkan mitra yang memiliki visi yang sama yaitu membentuk karakter anak-anak bangsa. Kemitraan dapat berupa dukungan terhadap program-program yang dibuat oleh pihak sekolah sebagai lembaga pendidikan formal. Kerjasama berupa dukungan tersebut akan memperlancar ketercapaian program-program sekolah dalam rangka penguatan pendidikan karakter.

Pada pendidikan formal peserta didik telah diajarkan dan dibimbing terkait dengan pengetahuan keagamaan sebagai dasar utama penguatan karakter. Pembelajaran tersebut diharapkan akan dapat menghasilkan peserta didik yang memahami agamanya baik secara teori maupun praktik, sehingga memiliki kesiapan untuk hidup dalam lingkungan masyarakat.

Pada lingkungan sekolah implementasi dari teori yang diperoleh hanya sebagian kecil dapat terimplementasi, karena dalam lingkungan sekolah anakanak harus menyelesaikan mata pelajaran lainnya sebagaimana disyaratkan oleh kurukulum satuan pendidikan. Keterbatasan waktu tersebut menjadikan peserta didik harus dapat lebih banyak mengimplementasikan ketika telah 
menyelesaikan pendidikan formal. Kehidupan seseorang selalu membutuhkan peran serta orang tua dan masyarakat dalam mengarahkan dan membimbingnya.

Orang tua dan masyarakat memberi pengawasan dan bimbingan sehingga ada sinergisitas dengan tujuan yang hendak di capai oleh pemerintah. Dukungan keluarga dan masyarakat dalam penguatan pendidikan karakter sangat di butuhkan, terutama bagi generasi muda yang menjadi harapan dalam pembangunan bangsa dan Negara. Masyarakat merupakan lingkungan tempat dilakukannya sebagian besar interaksi individu dengan beragam karakternya.

Pada lingkungan masyarakat terdapat beragam karakter dan sifat yang berbeda-beda, sehingga dalam lingkungan tersebut akan nampak karakter yang beragam. Keberagaman tersebut akan dapat mendidik sesesorang dalam menempatkan diri serta memposisikan diri dalam situasi yang mungkin belum pernah di alami sebelumnya.

Implementasi teori yang diperoleh dalam lembaga pendidikan formal lebih banyak akan berfungsi ketika hidup dalam masyarakat dengan beragam dinamikanya. Masyarakat secara tidak langsung dan tanpa terprogram melaksanakan pendidikan kebiasaan-kebiasaan yang secara turun temurun telah dilakukan. Beragam budaya dan tradisi yang hidup dan berkembang dalam lingkungan masyarakat sesungguhnya merupakan bagian dari pendidikan. Tanpa disadari banyak hal yang dapat menjadikan seseorang harus memulai untuk belajar dari masyarakat.

Proses belajar dari kebiasaan lingkungan sekitar terkadang kurang disadari sehingga sering diabaikan oleh beberapa orang karena dianggap hanya menjalankan apa yang menjadi kebiasaan dari orang tua sebelumnya secara turun temurun. Tradisi yang dilakukan dianggap hanya sebatas sebuah warisan leluhur yang harus dilakukan tanpa memahami bagian pendidikan yang ada didalamnya.

Pendidikan dapat diperoleh dari lingkungan sosial, karena interaksi dengan lingkungan sosial akan dapat memberikan sejumlah kemampuan yang dapat berguna bagi kelangsungan hidup seseorang. (Tirtarahardja \& Sulo, 2005) menjelaskan bahwa pendidikan diperoleh karena hasil interaksi manusia dengan lingkungannya, baik lingkungan fisik maupun lingkungan sosial manusia secara efesien dan efektif.

Apapun yang dilakukan oleh masyarakat sebagai bagian dari kebiasaan dan 
didasarkan pada kitab suci atau sastra lsuci sebagian besar terselipkan nilainilai pendidikan. Budaya-budaya yang hidup dan bertahan dalam lingkungan masyarakat sebagai bagian dari warisan leluhur sarat dengan nilai-nilai pendidikan. Melalui budaya-budaya tersebut pada jaman dahulu dijadikan sebagai media dalam pendidikan dari generasi ke generasi.

Masyarakat hindu sebagai masyarakat yang kaya akan tradisi dari leluhur memiliki keyakinan bahwa segala sesuatu yang ada disebabkan oleh sesuatu yang terjadi sebelumnya. Konsep tersebut menjadikan segala sesuatu yang dilakukan akan menghasilkan sesuatu sebagai pahala. Dari keyakinan tersebut memunculkan sebuah konsep hukum alam yang disebut dengan Karma Phala, atau hasil dari perbuatan. Kitab Sarasamuscaya 27 yang menjelaskan bahwa apa saja yang orang tabur, itulah hasil yang akan ia petik, (Kiriana, n.d.: 72).

Keadaan yang terjadi merupakan hasil dari sebuah sebab yang ada sebelumnya, karena segala sesuatu yang terjadi tidak lepas dari hukum sebab akibat. Perbuatan (karma) selalu menimbulkan akibat, subha karma adalah perbuatan baik, akan memberi pahala baik dan sebaliknya asubha karma adalah perbuatan buruk, akan menghasilkan pahala tidak baik, (Lilik \& Mertayasa, 2019).

Konsep karma phala menjiwai setiap gerak langkah pada kehidupan seharihari umat Hindu. Hal tersebut tampak dari adanya Karma Phala dalam dasar keyakinan umat Hindu yang disebut dengan Panca Sradha sebagai dasar setiap gerak langkah umatnya. Panca Sradha artinya lima dasar kepercayaan atau keyakinan yang harus diyakini oleh setiap pemeluk Hindu, (Kokog, n.d.). Panca Sraddha berarti lima kepercayaan dalam agama Hindu yang terdiri dari percaya akan adanya Tuhan, Atman, Karma phala, Reinkarnasi dan Moksa, (Kiriana, n.d.-b).

Kelima keyakinan tersebut selalu menjadi dasar dalam setiap gerak langkah yang dilakukan oleh umat Hindu. Setiap aktivitas yang dilakukan oleh manusia diyakini tidak dapat terlepas dari konsep karma. (Mertayasa, 2019: 107) menjelaskan kebebesan yaitu bersatunya Atman dengan Brahman ditentukan oleh karma dari masing-masing individu, dan manusia tidak bisa terlepas dari hukum karma.

Kelahiran manusia ke dunia (Punarbhawa) adalah untuk menjalani karma. Sehingga sejak manusia lahir membawa karmawasananya masing-masing. Proses kelahiran berulang adalah bagian dari pendidikan yang mengharapkan 
adanya perbaikan diri dari setiap kelahiran yang diperoleh sehingga kualitas kehidupan akan dapat terus meningkat. Peningkatan kualitas hidup akan membawa seseorang sampai pada tujuan akhir yaitu pencapai moksa.

Kitab bahagavad gita IV:5 menyebutkan "bahūni me vyatītāni janmāni tava cārjuna, tāny aham veda sarvāṇi na tvam vettha parantapa, Artinya: kau dan Aku telah melewati banyak masa kehidupan. Aku mengingat semuanya sementara kau tidak mengingatnya, Arjuna, (Krishna, 2018: 62).

Terdapat hubungan yang erat antara reinkarnasi manusia dengan ajaran Tri $R n a$, karena kelahiran menyebabkan manusia memiliki hutang yang wajib untuk dibayar. Ketiga hutang tersebut yang dalam ajaran agama hindu disebut dengn Tri Rna, adalah tiga hutang yang harus dibayar sehubungan dengan keberadaan manusia di dunia. Pratiwi, (2017: 83) menyebutkan bahwa Tri Rna terdiri dari Dewa Rna adalah kewajiban yang harus dilaksanakan kehadapan Ida Sang Hyang Widi Wasa; Rsi Rna adalah kewajiban yang harus dilaksanakan kehadapan para Rsi; Pitra Rna adalah kewajiban yang harus dilaksanakan kehadapan kepada para leluhur. Sastrawan, (2017: 116) menjelaskan hutang (Rna) kemudian dapat dibayar dengan melaksanakan upacara Yadnya yang dalam implementasinya dengan pelaksanaan Panca Yadnya.

Tri Rna sebagai sebuah hutang wajib untuk dibayar sehingga menjadi sebuah kewajiban yang harus dipenuhi oleh manusia dalam kehidupannya. Hutanghutang tersebut dibayar dengan melaksanakan Yadnya. Panca Yadnya sebagai implementasi dari Tri Rna, dalam pelaksanaanya tersirat nilai-nilai pendidikan. (Mertayasa, n.d.) menyebutkan bahwa tradisi yang diwariskan secara turun temurun jika ditinjau dari sudut pandang pendidikan memiliki banyak nilai-nilai pendidikan yang menopang kehidupan manusia.

Implementasi dari ajaran Panca Yadnya memiliki nilai yang dapat berfungsi sebagai penguat pendidikan Karakter (PPK). Oleh karena itu pelaksanaan dari pembayaran hutang bagi setiap manusia dalam keyakinan hindu adalah turut serta dalam mendukung proses penguatan karakter sebagaimana di amanatkan dalam Permendikbud Nomor 20 tahun 2018.

Beberapa masyarakat selama ini melaksanakan Yadnya sebagai bentuk kewajiban semata dan hanya usaha untuk menimbun karma baik selama hidupnya. Tanpa dipahami bahwa proses pelaksanaan Yadnya terselip hal-hal yang sifatnya untuk mendidik pelakunya. Proses pelaksanan Yadnya tersebut 
menjadi hal penting karena dapat dijadikan sebagai wadah dalam penguatan pendidikan karakter. Pemahaman yang mendasar dan menyeluruh terhadap tradisi-tradisi yang dilakukan oleh masyarakat termasuk dalam proses pelaksanaan Yadnya menjadi penopang pengembangan pendidikan.

Sejak dini ajaran Yadnya telah dikenalkan kepada generasi muda hindu, mulai dari jenjang sekolah dasar hingga Perguruan Tinggi bahkan dalam lingkungan masyarakat. Implementasi dari apa yang telah dipelajari perlu dibarengi dengan pemahaman dari berbagai aspek termasuk dalam penguatan nilai pendidikan karakter. Makna yang lebih komprehensif akan dieproleh terhadap pelaksanaan ajaran agama, sehingga dapat membantu pencapaian programprogram pemerintah terutama terkait dengan penguatan pendidikan karakter.

\section{Pembahasan (Tampung penyang_Heading1) 1. Konsep Tri Rna sebagai dasar pelaksanaan Yadnya.}

Secara etimologi Tri Rna berasal dari bahasa Sansekerta, yaitu Tri yang artinya tiga dan Rna yang artinya hutang atau kewajiban. Tri Rna merupakan tiga hutang yang yang dimiliki manusia sejak lahir. Tri Rna terdiri dari hutang kepada Dewa/Tuhan Yang Maha Esa (Dewa Rna) yang dibayar dengan melaksanakan Dewa Yadnya dan Bhuta Yadnya, hutang kepada leluhur (Pitra Rna) di bayar dengan melaksanakan manusia Yadnya dan pitra Yadnya dan hutang kepada para Rsi (Rsi Rna) di bayar dengan melaksanakan Rsi Yadnya.

\section{a. Dewa Rna}

Dewa Rna yaitu hutang kepada para Dewa sebagai manifestasi Ida Sang Hyang Widhi wasa yang menciptakan alam semesta beserta segala isinya. Para dewa memberi atman kepada semua mahluk termasuk manusia sehingga dapat hidup dan melaksanakan segala bentuk kewajiban yang dibebankan. Selain memberi kehidupan dewa sebagai manifestasi Ida Sang Hyang Widhi Wasa juga menciptakan alam sebagai tempat manusia dan mahluk lainnya untuk hidup. Adanya alam semesta menjadikan manusia dan mahluk hidup lainnya dapat melangsungkan kehidupannya.

Kitab Bahagavad Gita III.10 menyebutkan bahwa :

Sahayajñāh prajāh shrishtvā puro, 
'vācha prājapatih anena

prasavishya dhvam esa vo

'stv ishta kāmadhuk

Terjemahan:

Prajāpati Brahmā Sang Pencipta dan Penguasa makhluk-makhluk ciptaannya menciptakan umat manusia dengan semangat persembahan dan pesan-Nya ialah, Berkembanglah dengan cara yang sama (berkarya dengan semangat persembahan) dan raihlah segala kenikmatan yang kau dambakan, (Krishna, 2018: 46).

Tuhan menciptakan umat manusia beserta seluruh isi alam dengan dasar Yadnya/persembahan. Untuk menjaga semuanya itu juga harus dilakukan dengan yadnya. Kebahagiaan akan dapat diperoleh melalui yadnya.

Penciptaan yang dilakukan melalui manifestasi-Nya sebagai Dewa Brahma dengan sakti Dwi Saraswati. Sebagai manusia yang memiliki cipta, rasa dan karsa memiliki kewajiban untuk membalas jasa tersebut. Kewajiban tersebut dalam bentuk hutang ( $r n a$ ) kepada Ida Sang Hyang Widhi Wasa dengan segala manifestasinya.

Manusia sebagai mahluk yang diciptakan dengan yadnya menurut keyakinan agama hindu memiliki kewajiban untuk melaksanakan Yadnya. Hal itu dimaksudkan sebagai bentuk ucapan terima kasih atas apa yang telah diberikan Ida Sang Hyang Widhi Wasa/Tuhan Yang Maha Esa. Dewa Rna melahirkan kewajiban dalam melaksanakan upacara Dewa Yadnya dan bhuta Yadnya.

Impelementasi dari Dewa Yadnya dapat berupa 1). Melaksanakan persembahyangan untuk memuja kebesaran Tuhan; 2). Memelihara dan menjaga serta menyayangi segala ciptaan Tuhan; 3). Melaksanakan perintah dan menjauhi larangan Tuhan sebagaimana tuntunan Agama; 4). Melaksanakan Upacara Piodalan, baik di sanggah merajan maupun dipura; 5). Melaksanakan swadarma sebagai bentuk Yadnya kepada Tuhan. Sedangkan pelaksanaan Bhuta Yadnya dilakukan dengan melaksanakan pecaruan dan tawur agung. 


\section{b. Rsi Rna}

Rsi Rna adalah hutang budi kepada para Rsi/Orang suci. Seseorang dapat digolongkan ke dalam orang suci apabila telah disucikan dengan upakara atau orang-orang yang menerima wahyu serta memberikan pencerahan kepada umatnya. Kitab Bahagavad Gita menjelaskan keberadaan orang suci sebagai berikut :

yasya sarve samārambhāh

kāma-sañkalpa-varjitāh

jñānāgni-dagdha-karmāṇam

tam āhuḥ paṇditam budhāh

B.G. IV.9

Tejemahan:

Seseorang yang berkarya tanpa keinginan duniawi dan harapan akan imbalan, telah tersucikan seluruh karma, seluruh perbuatannya, oleh api kebijaksanaan sejati. Para paṇitita, mereka yang berpengetahuan pun menyebutnya seorang bijak, (Krishna, 2018: 67).

Para rsi merupakan orang yang memiliki pengetahuan serta terlepas dari ikatan duniawi. Pengetahuan yang dimiliki diberikan kepada umat manusia, sehingga dapat menjadi pedoman dalam menjalani kehidupan sehingga memperoleh kebahagiaan. Para Rsi atau orang suci berjasa dalam memberikan ilmu pengetahuan dan pemahaman agama serta bimbingan dalam pelaksanaan yadnya. Jasa tersebut menjadikan manusia memiliki kewajiban untuk melaksanakan Rsi Yadnya yaitu persembahan tulus ikhlas yang ditujukan kepada para rsi atau orang suci.

Implementasi Rsi Yadnya dapat dilaksanakan dalam bentuk kegiatan-kegiatan diantaranya yaitu 1). Tekun mempelajari kitab-kitab suci; 2). Menerapkan ilmu pengetahuan dan ilmu keagamaan yang telah di ajarkan oleh para maha rsi; 3). Pada Hari tertentu memberikan punia kepada para Rsi yang telah berjasa dalam memberikan pengetahuan suci; 4). Memberikan daksina kepada 
para Rsi yang telah menyelesaikan upacara; 5). Menyebarkan ajaran Weda serta mengembangkannya sesuai dengan situasi tertentu; 6). Melaksanakan Rsi Bojana.

\section{c. Pitra Rna}

Pitra Rna berarti hutang jasa kepada para leluhur baik yang telah meninggal maupun yang masih hidup. Leluhur yang telah meninggal akan menjadi pitara dan diyakini akan membantu seseorang dalam menjalani kehidupannya, serta menghindarkan dari mara bahaya dan berbagai macam bentuk musibah.

Pitra Rna adalah hutang kepada leluhur. Kata Pitra berasal dari bahasa sansekerta "pitr" yang berarti ayah atau bapak. Bentuk jamaknya adalah "pitara" yang berarti nenek moyang/leluhur, sehingga dapat diartikan sebagai hutang kepada orang tua atau leluhur/nenek moyang. Hutang kepada leluhur yang dimaksud ialah hutang mulai dari kepada orang tua sampai ketingkat diatasnya atau nenek moyang.

Orang tua merupakan leluhur yang masih hidup yang wajib untuk dihormati, dirawat dan dijaga. Orang tua memiliki jasa yang sangat besar dalam kehidupan seseorang, karena tanpa adanya orang tua seseorang tidak akan dapat mengalami kelahiran. Tuhan menggunakan orang Tua sebagai satusatunya perantara dalam melahirkan manusia kedunia.

Sejak dalam kandungan seseorang dijaga dan di rawat oleh orang tua. Bahkan pada satu keadaan tertentu orang tua mengorbankan kepentingannya untuk dapat memenuhi kepentingan anak-anaknya. Orang tua dalam menafkahi, menjaga dan merawat anak-anaknya menjadikan seorang anak memiliki hutang yang sesungguhnya tidak dapat dibayar secara sepadang oleh seorang anak terhadap jasa yang telah dilakukan. Jasa-jasa tersebut menjadikan manusia yang lahir ke dunia memiliki kewajiban untuk melaksanakan Pitra Yadnya.

Besarnya jasa orang tua yang telah merawat dan melahirkan serta pengorbanan yang diberikan kepada anaknya sesungguhnya tidak akan dapat dibayar. Manu Smrti 11.227 menyebutkan bahwa:

Yam matapitaram klecam

seheta sambhawe, 
Nrnam na tasya

niskrtih Cakya kartum

warsa catairapi

Terjemahannya :

Penderitaan yang diabaikan oleh Bapak dan Ibu pada waktu lahir anak (bayi) tidak dapat dibayar walaupun dalam waktu seratus tahun.

Walau demikian manusia selalu berkewajiban untuk selalu berusaha memberikan yang terbaik dan melakukan apa yang menjadi kewajiban tersebut dengan semaksimal mungkin. Banyak hal yang dapat dilakukan untuk dapat membahagiakan orang tua diantaranya yaitu dengan selalu mematuhi nasehatnya, menjadi anak yang baik, selalu hormat kepada orang tua, menjaga dan merawatnya serta hal-hal lainnya.

Menghormati orang tua disamping sebagai sebuah kewajiban yang timbul akibat dari jasa beliau, juga akan memberi kebahagiaan kepada anak yang selalu menghormati kedua orang tua mereka. Dalam Reg Veda II.41.14 disebutkan sebagai berikut :

Tivro vo madhumam ayam sunarhortre

Su matsarah etam pibata kamyam

Artinya:

Berbahagialah mereka yang menghormati orang tuanya, berbahagialah mereka yang menguasai ilmu pengetahuan.

Kewajiban yang timbul akibat dari jasa orang tua dan para leluhur menjadikan seorang anak wajib untuk melaksanakan ajaran Panca Yadnya khususnya adalah Manusia Yadnya dan Pitra Yadnya. Kedua Yadnya tersebut akan mampu membawa seseorang pada kebahagiaan dan terpenuhinya kewajiban 
kepada para leluhur. Hal yang terpenting dari pelaksanaan kedua yadnya tersebut adalah didasarkan atas rasa bhakti kepada para leluhur.

Manusia Yadnya dimaksudkan untuk membayar hutang kepada sesama manusia, sebagai mahluk sosial dan mahluk yang religius. Pelaksanaan manusia Yadnya adalah dengan melaksanakan upacara sejak dari adanya benih dalam kandungan hingga manusia meninggal.

Menurut keyakinan agama hindu manusia sejak di dalam kandungan telah dibuatkan sebuah upacara sebagai ucapan syukur. Upacara dilakukan selama hidup manusia yang disesuaikan dengan tahapan-tahapan yang telah di tentukan, seperti upacara bayi lahir, kepus pusar, upacara 42 hari, upacara 3 bulanan dan upacara laiinya, hingga manusia tersebut meninggal dunia.

Selain upacara manusia Yadnya, hutang kepada leluhur juga dilaksanakan dengan melaksanakan upacara pitra Yadnya, yang dimaksudkan untuk membayar hutang kepada para leluhur terutama yang telah meninggal dunia.

Kunti Yadnya menyebutkan menyebutkan sebagai berikut :

Kengetakna grtrani kawitanta,

Tkeng anak putunta sukula Bretya nucara,

me pwakita Panahura hutanganta ring yayah bibi,

panebusaning sarirakret ngaranya kasampurna dening yasa sembanta,

Terjemahannya :

Ingatlah jasa-jasa leluhurmu pada anak cucu serta pada seluruh sanak keluarga, patutlah membayar segala hutangmu pada Ayah Ibu.

Pelaksanaan upacara pitra Yadnya adalah upacara yang dilakukan ketika seseorang telah meninggal dunia. Hal tersebut sebagai sebuah kewajiban bagi pratisentana yang ditinggalkan. Pelaksanaan upacara pitra Yadnya diantaranya yaitu 1). Melaksanakan upacara ngaben bagi yang telah meninggal; dan 2). Menstanakan roh suci leluhur pada rong telu. 


\section{Pendidikan Karakter dalam pelaksanaan Yadnya}

Pendidikan Agama akan memungkinkan tumbuhnya hal-hal yang baik seperti gemar menolong, menghormati, rajin sembahyang dan kebiasaan positif lainnya. Pendidikan karakter dalam pelaksanaannya adalah merupakan penerapan nilai-nilai yang terkandung dalam dasar Negara yaitu Pancasila.

Permendikbud Nomor 20 Tahun 2018 pasal 2 ayat 1 menyebutkan bahwa PPK dilaksanakan dengan menerapkan nilai-nilai Pancasila terutama meliputi nilainilai religius, jujur, toleran, disiplin, bekerja keras, kreatif, mandiri, demokratis, rasa ingin tahu, semangat kebangsaan, cinta tanah air, menghargai prestasi, komunikatif, cinta damai, gemar membaca, peduli lingkungan, peduli sosial, dan bertanggung jawab. Selanjutnya Pasal 2 ayat 2 Permendikbud menyebutkan kelima nilai tersebut adalah 1). Religiusitas; 2). Nasionalisme; 3). Kemandirian; 4). Gotong Royong; dan 5). Integritas, (Tim, 2018).

Penguatan Nilai pendidikan karakter dalam pelaksanaan Panca Yadnya yang merupakan implementasi dari ajaran Tri Rna adalah sebagai berikut :

\section{a. Religiusitas}

Kata religiusitas berasal dari kata religius, Wiyono, (2007: 428) religiusitas berarti bersifat keagamaan, yang berkenaan dengan kepercayaan agama. Kaye \& Raghavan, (2000) menyatakan bahwa religiusitas adalah sebuah ekspresi Spiritual seseorang yang berkaitan dengan sistem keyakinan, nilai, hukum yang berlaku dan ritual, (Thontowi, n.d.: 1). Religiusitas merupakan ketaatan seseorang dalam menjalankan ajaran agamanya yang diwujdukan dalam bersikap dan bertindak sesuati dengan ajaran agama yang dianutnya.

Glock dan Stark (1966) menyatakan bahwa religiusitas sebagai sebuah komitmen beragama, yang dijadikan sebagai dasar kebenaran beragama, yang dilakukan seseorang sebagai bagian dari kepercayaan, bagaimana emosi atau pengalaman yang disadari seseorang tercakup dalam agamanya, dan bagaimana seseorang hidup dan terpengaruh berdasarkan agama yang dianutnya, (Nuandri \& Widayat, 2014: 63-64).

Religiusitas dapat dimaknai sebagai tindakan yang dilakukan oleh seseorang dalam kehidupan sehari-hari yang didasarkan pada nilai dan emosi keagamaan. Oleh karena itu dalam rangkaian pelaksanaan Panca Yadnya terdapat rangkaian persembahyangan untuk memuja keagungan dan 
kemahakuasaan tuhan sekaligus sebagai ucapan terima kasih atas segala karunia-Nya.

Persembahyangan yang dilakukan seseorang sebagai kewajiban atas hidup yang telah di berikan. Pelaksanakan persembayangan merupakan salah satu indikator terhadap tingkat iman dan keyakinan seseorang akan sang pencipta.

Persembahyangan dilaksanakan karena adanya keyakinan akan Tuhan sebagai penyebab segala sesuatu yang ada. Glock menyebut hal terebut sebagai bagian religiusitas dalam dimensi ideologi (Ideological dimention) yaitu kemampuan seseorang dalam menerima hal-hal yang dogmatis dalam ajaran agamanya, termasuk didalamnya adalah keyakinan akan adanya Tuhan serta kemahakuasaan-Nya, (Amawidyati, Sukma Adi Galuh Utami, n.d.: 168).

Wujud terima kasih di aktualisasikan dalam bentuk bhakti kepada Tuhan. Krishna, (2018: 189-190) menyebutkan bahwa bhakti merupakan ungkapan kasih yang tak terbatas; cinta, yang tak terhingga dan tanpa syarat, pemekaran cinta sejati ketika cinta menjadi devosi, persembahan tanpa syarat.

Persembahan atau bhakti di laksanakan secara tulus iklas, dan dilakukan dengan memusatkan dan menyerahkan diri sepenuhnya. Kitab Bhagavad Gita XII. 6-7 menyebutkan sebagai berikut :

ye tu sarvāṇi karmāṇi mayi samnnyasya mat-paraḥ ananyenaiva yogena mām dhyāyanta upāsate.

teșām aham samuddhartā mṛtyu-saimsāra-sāgarāt bhavāmi na cirāt pārtha mayy āveśita-cetasām.

Terjemahannya :

Sebaliknya, mereka yang senantiasa berkarya dengan semangat persembahan pada-Ku; memuja- Ku sebagai Hyang Maha Mewujud; memusatkan seluruh kesadarannya pada-Ku tanpa terganggu oleh sesuatu; wahai Arjuna, niscayalah Ku-bantu menyeberangi lautan samiāra, kelahiran dan kematian yang berulang-ulang ini. 
Lautan samsara yaitu kehidupan yang berulang akan dapat terlewati dengan selalu memusatkan seluruh kesadaran hanya kepada Tuhan. Melakukan pemujaan dengan tulus serta menyerahkan seluruh hasilnya kepada Tuhan. Wujud bhakti tersebut dapat pula dilakukan dengan selalu menjaga dan memelihara ciptaa-Nya serta melakukan Yadnya.

Pelaksanaan Yadnya pada dasarnya mengajarkan kepada umatnya untuk selalu mendekatkan diri dan bersikap tulus iklas terhadap apapun yang telah dilakukan. Yadnya yang dilakukan dapat meningkatkan keyakinan akan kemahakuasaan Tuhan. Pelaksanaan Yadnya menjadikan seseorang lebih dekat kepada Tuhan, menjauhi larangan dan melaksanakan semua perintahNya. Hal tersebut merupakan bagian dari penguatan nilai religiusitas sebagai bagian dari penguatan pendidikan karakter.

\section{b. Komunikatif}

Komunikatif merupakan kemampuan seseorang dalam melakukan komunikasi sesuai dengan sistuasi yang ada. Berkomunikasi memiliki peranan penting dalam kehidupan sosial, karena komunikasi menjadikan seseorang paham apa yang dimaksudkan oleh orang lain.

Rangkaian pelaksanaan Yadnya selalu melibatkan orang lain, oleh karena itu akan selalu terjadi percakapan dari satu orang dengan orang lainnya. Keadaan tersebut menjadikan seseorang untuk mampu melakukan komunikasi dengan baik, sehingga semua aktifitas pelaksanaan Yadnya dapat berlangsung dengan baik.

Pelaksanaan Yadnya karena melibatkan banyak orang, secara otomatis akan terjadi interaksi antar individu. Proses interaksi tersebut akan menjadikan seseorang lebih terlatih untuk berkomunikasi, baik komunikasi dengan orang yang memiliki kasta yang sama, maupun dengan orang suci.

Terdapat perbedaan cara berkomunkasi dengan orang suci dengan masyarakat kebanyakan. Komunikasi dengan orang suci sebagai orang yang dihormati biasanya menggunakan tata bahasa dalam tingkatan utama. Apabila berkomunikasi dengan orang yang memiliki kasta yang lebih rendah dapat menggunakan bahasa yang orang kebanyakan gunakan, akan tetapi tetap untuk memperhatikan tata bahasa yang pantas untuk diucapkan. 
Proses pelaksanaan Yadnya secara tidak langsung memberikan pengetahuan terkait dengan bagaimana melakukan komunikasi, dengan memperhatikan kepada siapa komunikasi tersebut dilakukan. Hal ini karena dalam sebuah Yadnya akan terdapat orang suci sebagai pemuput Yadnya, yang etika dalam berbicara menggunakan bahasa yang halus.

Yadnya menjadikan seseorang untuk lebih komunikatif, karena mulai dari persiapan hingga pelaksanaan Yadnya tidak terlepas dengan interaksi dengan orang lain. Oleh karena itu pelaksanaan Yadnya secara tidak langsung mendidik untuk seseorang untuk berkomunikasi dan menjadikan seseorang lebih komunikatif.

\section{c. Kerjasama (Gotong royong)}

Gotong royong adalah bekerja bersama-sama dalam mengerjakan sesuatu, dapat pula diartikan sebagai keadaan tolong-menolong dalam menyelesaikan suatu pekerjaan. Manusia sebagai mahluk social tidak terlepas dari keberadaan orang lain. Seseorang akan membutuhkan orang lain dalam menjalani kehidupannya. Keberadaan orang lain untuk menolong dan ditolong akan dapat memudahkan dan meringankan beban yang dialami seseorang.

Pelaksanaan Yadnya tidak dapat dilakukan seorang diri tanpa ada bantuan orang lain. Seseorang yang melaksanakan Yadnya membutuhkan orang lain agar mendapatkan hasil sesuai dengan yang di harapkan. Orang lain akan memberikan kontribusi dalam pelaksanaan sebuah Yadnya.

Budaya untuk saling tolong menolong dalam sebuah kegiatan keagamaan sudah menjadi tradisi nenek moyang sejak lama. Budaya tersebut ada dalam lingkungan organisasi tradisional yang disebut dengan banjar, tempek atau istilah lain yang digunakan untuk menyebut organisasi tradisional masyarakat hindu. Anggota organisasi terlibat secara maksimal dalam pelaksanaan sebuah Yadnya, sehingga ketika seseorang memiliki Yadnya akan nampak adanya sebuah keramaian.

Kerjasama dalam kelompok dengan saling bahu membahu untuk menyelesaikan sebuah Yadnya menjadi bagian yang sangat penting dalam sebuah Yadnya. Istilah yang digunakan ketika membantu seseorang dalam menyelesaikan Yadnya adalah istilah ngayah/ngopin. 
Keterlibatan orang lain dalam pelaksanaan Yadnya mencirikan adanya sistem gotong royong dalam pelaksanaanya. Budaya tersebut bermotif karena adanya saling membutuhkan pada setiap manusia. Pada saat tertentu terutama saat mengadakan sebuah upacara baik dewa, pitra, manusia, rsi maupun bhuta Yadnya, anggota banjar/tempek akan saling bahu membahu untuk mensukseskan upacara tersebut. Oleh karena itu banjar biasa disebut dengan istilah organsiasi suka-duka. Penyebutan oraganisasi tersebut, dikarenakan adanya kebersamaan dalam keadaan suka maupun dalam keadaan duka.

Organsiasi suka duka menjunjung tinggi budaya gotong royong, karena dalam pelaksanaanya tidak terdapat upah atau imbalan. Keseluruhan kegiatan membantu tersebut dilaksanakan secara tulus iklas tanpa pamrih. Bagi beberapa orang menjadikan hal tersebut adalah sebuah Yadnya, karena yang dilakukan adalah sebuah wujud bhakti kepada Ida Sang Hyang Widhi Wasa.

Terlaksananya sebuah Yadnya tidak terlepas dari kerjasama untuk saling tolong menolong. Oleh karena itu sesungguhnya ketika seseorang menolong untuk bersama-sama menyelesaikan sebuah pekerjaan, adalah merupakan sebuah sikap gotong rooyong. Demikian halnya dalam pelaksanaan Yadnya sangat lekat dengan budaya gotong royong, yang juga merupakan salah satu dari nilai karakter.

Pelaksanaan Yadnya yang di dalamnya terdapat budaya gotong royong tanpa disadari merupakan upaya dalam mengatkan pendidikan karakter individu yang terlibat didalamnya. Untuk itu pelaksanaan kegiatan-kegiatan keagamaan yang melibatkan bantuan banyak orang, perlu untuk dipertahankan dan ditingkatkan, karena secara ekplisit hal tersebut merupakan penguatan pendidikan karakter.

\section{d. Bertanggung Jawab}

Bertanggungjawab merupakan sikap memiliki komitmen dalam menjalankan apa yang menjadi tugasnya. Bertanggung jawab dapat terjadi dalam berbagai aspek kehidupan, pekerjaan, rumah tangga, lingkungan sosial dan aspek lainnya.

Pelaksanaan Yadnya yang dilakukan oleh individu yang hidup dalam kelompok masyarakat seperti banjar/tempek, menganut system "berat sama dipikul, ringan sama di jinjing". Keadaan tersebut mengindikasikan bahwa 
setiap individu memiliki tanggung jawab yang sama dalam pelaksanaan sebuah Yadnya, terutama Yadnya yang dilaksanakan oleh desa adat.

Yadnya yang dilaksanakan oleh seseorang dalam lingkungan banjar/tempek membutuhkan bantuan dari masyarakat sekitarnya. Sebagian besar yang memiliki Yadnya (sang yajamana) melimpahkan tanggunjawab sepenuhnya kepada anggota banjar untuk mengelola Yadnya tersebut. Dengan demikian masyarakat turut serta memiliki tanggung jawab dalam keberlangsungan Yadnya tersebut.

Penyiapan sarana dan pelaksanaan Yadnya biasanya terdapat pembagian tugas, sehingga setiap orang akan mendapatkan tugas baik yang dilaksanakan secara berkelompok maupun secara mandiri. Tugas tersebut menjadi sebuah tanggung jawab yang harus dilaksanakan dengan sebaik mungkin.

Bagi individu yang melaksanakan Yadnya, juga memiliki tanggung jawab untuk membantu Yadnya yang dilakukan orang lain sebagai balas budi terhadap Yadnya yang pernah dilakukannya. Oleh karena itu dalam kegiatan Yadnya akan membentuk sebuah sistem, yang terus berputar dalam penyiapan dan pelaksanaan Yadnya.

Setiap pelaksanaan membutuhkan tanggungjawab, baik dari pemilik Yadnya maupun orang yang membantu pelaksanaanya. Tanggung jawab tersebut dipahami sebagai balas budi antar anggota masyarakat dalam kelompok tertentu. Apapun motif yang dimiliki sehingga seseorang memiliki tanggung jawab terhadap apa yang menjadi tugasnya adalah merupakan sebuah pembelajaran khususnya terkait dengan penguatan karakter.

\section{e. Kepedulian Sosial}

Kepedulian sosial merupakan kepekaan individu dalam melihat kehidupan sosial sekelilingnya. Keadaan sekelilingnya akan menjadikan seseorang untuk dengan cepat dan cermat mengambil sebuah tindakan ataupun sikap. Kepedulian sosial sangat dibutuhkan dalam kehidupan bermasyarakat, karena sikap tersebut akan dapat membentuk kehidupan sosial yang teratur.

Yadnya yang dilaksanakan oleh seorang individu selalu di bantu oleh orang lain. Hal tersebut merupakan salah satu bentuk kepedulian sosial yang dibangun oleh masyarakat. Kegiatan membantu sang yajamana karena merasa perduli akan orang lain. Demikian juga sebaliknya orang yang sudah pernah 
memiliki Yadnya akan perduli terhadap orang lain yang akan melaksanakan Yadnya, sehingga dapat terlibat dalam pelaksanaan Yadnya tersebut. Demikianlah idealnya kehidupan masyarakat yang baik, sehingga kehidupan bermasyarakat akan tentram dan damai.

Bentuk kepedulian terhadap sesama baik suka maupun duka merupakan wujud dalam penguatan pendidikan karakter yang perlu terus diperkuat dan dikembangkan dalam kehidupan bermasyarakat. Hal tersebut perlu diajarkan kepada generasi muda sehingga memiliki pemahaman yang komprehensif, sehingga Yadnya tidak hanya di maknai sebagai upacara ritual belaka, namun juga bagian dari pendidikan.

\section{Simpulan}

Setiap manusia sesuai dengan ajaran agama hindu tidak perna lepas dari pelaksanaan Yadnya, dari manusia dalam kandungan hingga meninggal dunia selalu di barengi dengan Yadnya. Pelaksanaan Yadnya didasari oleh adanya Tri Rna, terdiri dari hutang kepada Dewa/Tuhan Yang Maha Esa (Dewa Rna) yang dibayar dengan melaksanakan Dewa Yadnya dan Bhuta Yadnya, hutang kepada leluhur (Pitra Rna) di bayar dengan melaksanakan manusia Yadnya dan pitra Yadnya dan hutang kepada para Rsi (Rsi Rna) di bayar dengan melaksanakan Rsi Yadnya.

Setiap Yadnya yang dilaksanakan dapat menguatkan karakter sehingga merupakan pendidikan bagi setiap orang yang terlibat didalamnya. Pendidikan karakter yang dikuatkan dari pelaksanaan Yadnya adalah 1). Religiusitas, Yadnya tidak terlepas dari hubungan dengan sang pencipta, sehingga pelaksanaan Yadnya pada dasarnya mengajarkan kepada umatnya untuk selalu mendekatkan diri dan bersikap tulus iklas; 2). Komunikatif, pelaksanaan Yadnya melibatkan banyak orang termasuk orang-orang suci, sehingga akan terjadi interaksi di dalamnya. Proses interaksi tersebut menjadikan seseorang lebih terlatih untuk berkomunikasi; 3). Kerjasama (Gotong royong), pelaksanaan Yadnya tidak dapat dilakukan seorang diri tanpa ada bantuan orang lain. Kerjasama dalam kelompok dengan saling bahu membahu untuk menyelesaikan sebuah Yadnya; 4). Bertanggung Jawab, penyiapan sarana dan pelaksanaan Yadnya biasanya terdapat pembagian tugas, sehingga setiap orang akan mendapatkan tugas baik yang dilaksanakan secara berkelompok maupun secara mandiri; 5). Kepedulian Sosial, Yadnya yang dilaksanakan 
oleh seorang individu selalu di bantu oleh orang lain. Hal tersebut merupakan salah satu bentuk kepedulian sosial yang dibangun oleh masyarakat.

Berbagai bentuk karakter yang dikuatkan dengan pelaksanaan Yadnya, baik bagi pelaku maupun orang-orang yang membantu pelaksanaanya. Kelompok suka duka merupakan organiassi tradisional hindu yang menjadi wadah dalam penguatan pendidikan karakter. Hal tersebut perlu diajarkan kepada generasi muda sehingga memiliki pemahaman yang komprehensif, dan Yadnya tidak hanya di maknai sebagai upacara ritual belaka, namun juga bagian dari pendidikan.

\section{Daftar Pustaka}

Amawidyati, Sukma Adi Galuh Utami, M. S. (n.d.). Religiusitas dan Psychological Well-Being Pada Korban Gempa. Jurnal Psikologi, 34(2), 164-176. https://doi.org/10.1007/978-3-540-85867-6_16

Kiriana, N. (n.d.-a). Sinkretisme Dalam Agama Hindu Dan Buddha di Bali. Jurnal Penjaminan Mutu, 71-78. Retrieved from http://www.ejournal.ihdn.ac.id/index.php/JPM/article/viewFile/52/61

Kiriana, N. (n.d.-b). Sinkretisme Dalam Agama Hindu Dan Buddha di Bali. Jurnal Penjaminan Mutu, 71-78. Retrieved from http://www.ejournal.ihdn.ac.id/index.php/JPM/article/viewFile/52/61

Kokog, N. (n.d.). Panca Sradha. 25-26. Retrieved from https://id-static.zdn.net/files/d09/30809befff5a89c2071bee6fd2be0f8c.pdf

Krishna, A. (2018). Bhagavad-Gìtā Transkreasi Baru untuk Zaman Baru. Retrieved from https://bhagavadgita.or.id/\#daftar_isi

Lilik, L., \& Mertayasa, I. K. (2019). Esensi Tri Hita Karatriesensi Tri Hita Karana Perspektif Pendidikan Agama Hindu. Bawi Ayah: Jurnal Pendidikan Agama Dan Budaya Hindu, 10(2), 60-80. https://doi.org/10.33363/BA.V10I2.373

Mertayasa, I. K. (n.d.). Nilai-Nilai Pendidikan Pada Tradisi Ngayah Di Pura Agung Tri Buana Sari, Desa Mako, Kecamatan Pamona Barat, Kabupaten Poso. 2012, 1-104.

Mertayasa, I. K. (2019). Hoax Dalam Perspektif Hindu. Satya Widya: Jurnal Studi Agama, 2(1), 101-120. https://doi.org/10.33363/swjsa.v2i1.57 
Nuandri, V. T., \& Widayat, I. W. (2014). Hubungan Antara Sikap terhadap Religiusitas dengan Sikap terhadap Kecenderungan Perilaku Seks Pranikah pada Remaja Akhir yang Sedang Berpacaran di Universitas Airlangga Surabaya. Jurnal Psikologi Kepribadian Dan Sosial, 3(2), $60-69$.

Pratiwi, N. W. K. (2017). Kecamatan Klungkung Kabupaten Klungkung ( Perspektif Pendidikan Agama Hindu ). Jurnal Penelitian Agama Hindu, $1(2), 82-86$.

Sastrawan, K. B. (2017). Pendidikan Karakter dalam Upacara Kepus Puser. Genta Hredaya, 1(1), 115-122. Retrieved from http://www.ejournal.ihdn.ac.id/

Thontowi, A. (n.d.). Hakekat Religiusitas. Palembang: Widyaiswara Madya Balai Diklat Keagamaan.

Tim. (2003). Undang-Undang Republik Indonesia Nomor 20 Tahun 2003 Tentang Sistem Pendidikan Nasional.

Tim. (2018). Peraturan Menteri Pendidikan Dan Kebudayaan Republik Indonesia Nomor 20 Tahun 2018 Tentang Penguatan Pendidikan Karakter Pada Satuan Pendidikan Formal. Retrieved from https://jdih.kemdikbud.go.id/arsip/Permendikbud_Tahun2018_Nomor2 0.pdf

Tirtarahardja, U., \& Sulo, S. L. La. (2005). Pengantar Pendidikan. Jakarta: Rineka Cipta.

Wiyono, E. H. (2007). Kamus Bahasa Indonesia Lengkap Disertai Penggunaan EYD (Ejaan Yang Disempurnakan). Jakarta: Palanta. 